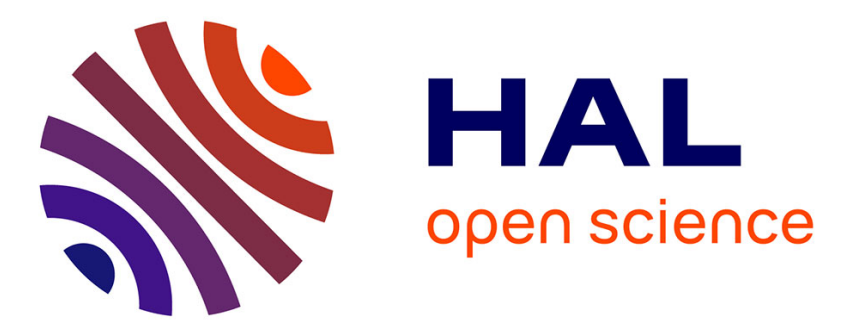

\title{
Ring density record of phenotypic plasticity and adaptation to drought in Douglas-fir
}

\author{
Alejandro Martinez Martinez-Meier, Léopoldo Sanchez, Guillermina G. Dalla \\ Salda, Leonardo Gallo, Mario Pastorino, Philippe P. Rozenberg
}

\section{To cite this version:}

Alejandro Martinez Martinez-Meier, Léopoldo Sanchez, Guillermina G. Dalla Salda, Leonardo Gallo, Mario Pastorino, et al.. Ring density record of phenotypic plasticity and adaptation to drought in Douglas-fir. Forest Ecology and Management, 2009, 258 (5), pp.860-867. hal-02655697

\section{HAL Id: hal-02655697 https://hal.inrae.fr/hal-02655697}

Submitted on 29 May 2020

HAL is a multi-disciplinary open access archive for the deposit and dissemination of scientific research documents, whether they are published or not. The documents may come from teaching and research institutions in France or abroad, or from public or private research centers.
L'archive ouverte pluridisciplinaire HAL, est destinée au dépôt et à la diffusion de documents scientifiques de niveau recherche, publiés ou non, émanant des établissements d'enseignement et de recherche français ou étrangers, des laboratoires publics ou privés. 


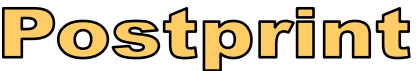

Version définitive du manuscrit publié dans / Final version of the manuscript published in :

Forest Ecology and Management. 2009, 258 (5), 860-867

Ring density record of phenotypic plasticity and adaptation to drought in Douglas-fir.

\author{
Alejandro Martinez-Meier ${ }^{1,2 *}$, Leopoldo Sanchez ${ }^{2}$, Guillermina Dalla-Salda ${ }^{2,3}$, Leonardo \\ Gallo $^{1}$, Mario Pastorino ${ }^{4}$, Philippe Rozenberg ${ }^{2}$.
}

${ }^{1}$ INTA Bariloche, Unidad de Genética Forestal, C.C. 277, (8400), San Carlos de Bariloche, Argentina. Email: almarti@bariloche;inta.gov.ar

* ²INRA Orléans, Unité Amélioration Génétique et Physiologie Forestières, 2163 Avenue de la Pomme de Pin, CS 40001 Ardon, 45075 Orléans Cedex 2, France. Email :

alejandro.martinez@orleans.inra.fr

${ }^{3}$ INTA Bariloche, Grupo de Ecología Forestal, C.C. 277, (8400), San Carlos de Bariloche, Argentina.

${ }^{4}$ Consejo Nacional de Investigaciones Científicas y Técnicas (CONICET), C.C. 277, (8400), San Carlos de Bariloche, Argentina.

* Corresponding author addresses

Telephone number: +33+238417873

Fax number: $+33+238417879$

Email: alejandro.martinez@orleans.inra.fr

Keywords: microdensity; climate change; Pseudotsuga menziesii. 


\begin{abstract}
Microdensity profiles of Douglas-fir's clones and weather data were used to study phenotypic plasticity (dendroplasticity). Within-ring microdensity was interpreted as the variation of tree response to weather-controlled changes of water balance during selected growing-seasons. An original norm of reaction was obtained by pairing evident points of abrupt changes in the ring microdensity profiles and in the weather indices. The coefficients of the non-linear models adjusted to the reaction norms were analysed as dendroplasticity variables. Dendroplasticity variables were significantly different between geographical locations, years and clones. Heritability of the dendroplasticity variables ranged from low to high and was similar to heritability values of microdensity variables such as mean ring density (MRD). Coefficients of genetic variation of dendroplasticity variables were intermediate between those of wood density and growth variables. Dendroplasticity variables were phenotypically and genetically related to ring microdensity variables, more strongly to latewood variables. Dendroplasticity provides retrospective, synthetic and easy-to-interpret information about tree response to the variation of the balance between water availability and water demand during the growing season. The proposed model of dendroplasticity is described by a number of parameters that are linked to a biological meaning. Our results suggest that there is a potential for adaptation to drought in Douglas-fir, with two mechanisms involved: at individual level, short-term plastic response during the growing season and, at population level, long-term, betweengeneration, evolution process.
\end{abstract}




\section{Introduction}

Douglas-fir (Pseudotsuga menziesii (Mirb.) Franco) is an important exotic forest species abundantly planted in Europe, mainly in France (De Champs, 1997; Thivolle-Cazat, 2004). This species is particularly sensitive to a reduction of water availability during the growing season (Silen, 1978; Rozenberg and Pâques, 2004; Martinez-Meier et al., 2008a). It has been recently affected by extreme climate events like the 2003 drought and heat wave in Europe, with symptoms ranging from partial to complete foliage necrosis (DSF, 2004; Martinez-Meier et al., 2008b).

A warming climate scenario is predicted (IPCC 2001; 2007), where extreme climate events, like the one in 2003, are expected to increase in frequency and intensity (Meehl et al., 2004; Stott et al., 2004; IPCC 2007). This is a challenge for the survival of vulnerable tree species. Douglas-fir adaptation to the future climate conditions may materialize through different complementary universal processes: exhibiting phenotypic plasticity, through gamete and/or seed dispersal onto new favorable habitats, and through in situ population evolution (Rehfeldt et al., 2001; Rehfeldt et al., 2002; St-Clair and Howe, 2007). Climate change appears to be rapid in the last decades. The rate of change may result too rapid for a single tree generation to adapt (St-Clair and Howe, 2007). If the celerity of this climatic change is confirmed in the next years, evolution and migration may play very minor roles in the survival of tree species (Noss, 2002; Rehfeldt et al., 2002; Savolainen et al., 2004). On the contrary, phenotypic plasticity, phenotypic by environment dependencies (DeWitt and Scheiner, 2004), may appear as the most important key process in tree acclimation to unpredictable environmental trends (Bradshaw, 1965; Bradshaw and Hardwick, 1989) and in the context of the rapid climate changes (Bréda et al., 2006).

Wood record across the tree's life is a measure of individual phenotypic plasticity to climate. In temperate climate wood is formed during a limited part of the year, the growing season. 
Variations of water balance during the growing season affect cambium activity (Zahner, 1968; Glerum, 1970; Larson, 1994), resulting in variation of the morphology of the xylem cells. These anatomical changes, from thin cell-walls and greater lumen diameters to thicker cell-walls and smaller lumen diameters closely follow weather variations, from wet to dry within the growing season (Larson, 1963; 1994). Thus anatomical differences appear as a plastic reaction to environmental changes. These anatomical changes do not come without a function, as small capillaries have increased resistance to negative tensions, allowing trees to maintain the integrity of their hydraulic system under lower water availability (Hacke et al., 2001; Domec and Gartner, 2002; Taiz and Zeiger, 2006).

In Douglas-fir, microdensity is strongly related to anatomy (Rathgeber et al., 2006). Wood microdensity profiles are integrated measures of wood anatomy. Unlike anatomy, microdensity requires less complex analytical approaches. Recent results show that Douglasfirs surviving to the 2003 drought and heat wave have significantly different microdensity profiles over time before the event compared to non-surviving neighbors (Martinez-Meier et al., 2008b), underlining a potential use of microdensity as an adaptation marker.

The evaluation of phenotypic plasticity requires the construction of a norm of reaction (NoR), a phenotypic response by a given genotype to an environmental gradient (Sarkar, 1999; Fuller, 2003; Gibert et al., 2004). The NoR obtained from a microdensity profile is denoted here with the neologism dendroplasticity. A preliminary study on maritime pine (Pinus pinaster) (Sanchez-Vargas et al,. 2007) showed a basic approach to construct a dendroplasticity NoR where the within-ring microdensity variation is related to withingrowing season weather variation. Sanchez-Vargas et al. (2007) fitted linear models for measuring dendroplasticity in one growing-season (1996) in three clonal sites with different clone composition, using different drought indices for each site. In this study we improve the model used by Sanchez-Vargas et al. (2007) by the use of a unique, biologically more Forest Ecology and Management, 258 (5), 860-867. 
realistic, non-linear model to relate the ring microdensity profile with the corresponding within-growing season weather index. We hypothesise that Douglas-fir can adapt its genetic structures to the future climate conditions and that we can study this phenomena by using wood as a record of tree response to climate. We expect that our results provide information about the adaptation of this species to the on-going global climate change and that they can be used within the frame of its breeding programs.

\section{Material and Methods}

Plant material comes from three different experimental clonal trials placed in: Lartimache (West of Massif-Central, Limousin), Chassenoix (Northeast of Massif-Central, Morvan) and Sorèze (South of Massif-Central, Midi-Pyrénées). The same material was also the object of a precedent study concerning the genetic response of Douglas-fir clones to the 2003 drought and heat wave in France (Martinez-Meier et al., 2008a). We used $5 \mathrm{~mm}$ increment cores taken at breast height. Increment cores were analyzed by indirect X-ray densitometry (Polge, 1966) and the resulting X-ray films were scanned. The digital images were processed with WinDENDRO software (Guay et al., 1992), obtaining a final spatial resolution of $25 \mu \mathrm{m}$. To study dendroplasticity it is necessary to synchronize within-ring microdensity variations and weather variations, since wood microdensity profiles are expressed in a distance scale while weather variations come in a time scale (Guay et al., 1992). This synchronization is possible assuming that: a) during the growing season, cambium reacts to weather variations; and b) this reaction is recorded in wood. In this study we used rings with a conspicuous characteristic known as false ring. A false ring is a band of high density wood included in the earlywood, which is known to be low density wood. False rings are responses to particular environmental events in the climatic record. They have already been used to study tree's response to drought constraints (Larson, 1963; Rozenberg et al., 2002). Most microdensity 
profiles present in each site and year false rings that can be matched to particular climate events, and thus helping to synchronize the distance scale in the microdensity profiles with the time scale in the growing season (Sanchez-Vargas et al., 2007) (Fig. 1a). For each studied site and year we identified different number of points (called breakpoints) to describe withinring microdensity variation. We assessed for each tree-ring breakpoints density $\left(\mathrm{d}_{\mathrm{i}}\right)$ and breakpoints position $\left(\mathrm{p}_{\mathrm{i}}\right)$.

A drought index (DI) characterizes weather variation (Fig. 1b). The DI was computed from weather data provided by Météo France from the closest meteorological stations. It was based on the index of De Martonne (De Martonne, 1926), computed using simple climate variables as: the maximum and minimum daily temperature and precipitation (mm). For each site and year, the same numbers of weather points (DI value) were identified assuming that breakpoint density variation can be explained by weather DI value.

\section{Fig. 1}

We selected for this study the 1996 and 1998 ring-years in Lartimache and Sorèze, and the years 1996 and 2001 in Chassenoix (Table 1). The selected year-rings showed similar patterns of microdensity variation. False peaks determined a characteristic shape in all trees. We used the profiles of 138 trees from 30 different clones in Lartimache; 102 trees from 22 different clones in Sorèze and 104 trees from 23 different clones in Chassenoix. Nine clones are common to the three sites. The replication of several genotypes across three sites allows us to separate the geographical and genetic effects in the estimation of the inter-site phenotypic variation for dendroplasticity.

\section{Table 1}


For each site and year, non-linear sigmoidal Boltzmann function was fitted to estimate individual NoR by means of the following expression:

$$
y_{x, a, b, c, d}=b+\frac{c-b}{\left(1+e^{(a(x-d))}\right)}
$$

where: $y_{x, a, b, c, d}$ is the observed breakpoint density, $a$ is the slope of the curve, $b$ is the ground asymptote and was fitted to zero, $c$ is the maximum asymptote and $d$ is the inflexion point. Ground asymptote was fitted to zero because we consider that breakpoints density in this portion of the ring was formed under favourable water balances and thus does not represent a response to drought constraints, but only the value of wood microdensity at the beginning of the growing-season. The resulting NoR measures dendroplasticity. Boltzmann coefficients provide characteristic values, which have a clear biological meaning: $a$ represents the directional increment in wood density in response of trees to drought constraint (hereafter SLO). For instance, the more the negative value of SLO the more rapid the change of wood density in relation to DI increment will be. $C$ define the intensity value of tree response to drought constraints toward the final part of the growing season, when water limitations are more severe (hereafter INT); whereas $d$, could be interpreted as the susceptibility of tree to drought, because it determines the position of the curve on the abscissa and gives the value of DI corresponding to $50 \%$ wood density increase (hereafter SUS). SLO, INT and SUS define dendroplasticity variables at individual tree. The non-linear sigmoidal Boltzmann models were adjusted using the $d r m$ function in the $d r c$ library of the $\mathrm{R}$ software (R Development Core Team 2008).

\section{Fig. 2}


The following ring variables were also calculated: ring width (RW), mean ring density (MRD), minimum ring density (MID), maximum ring density (MAD), earlywood and latewood width (EW and LW, respectively), earlywood and latewood mean density (EWD and LWD, respectively), earlywood proportion (EWP), mean density point (MDP) defined as: (MID+((MAD-MID)/2)) and within-ring standard deviation as a measure of the intra-ring density dispersion (STD). Earlywood (or latewood) mean density was computed as the average ring density of all values lower (or higher) than the MDP. Earlywood and latewood ring width were computed as the distance from the ring's beginning to the MDP position, and from MDP to the end of the ring, respectively (Zamudio et al., 2005).

The nine clones common to the three sites allow compute inter-site phenotypic variation of dendroplasticity in the only year in common to the three sites (1996), by means of the following ANOVA model:

$y_{i j k}=\mu+\tau_{i}+\beta_{j}+(\tau \beta)_{i j}+\varepsilon_{i j k}$

where: $y_{i j k}$ is the ${ }_{k}$ th dendroplasticity variable observable in the ${ }_{i}$ th site and the ${ }_{j}$ th level of factor clone, $\mu$ is the overall mean effect, $\tau_{i}$ is the fixed effect of ${ }_{i}$ th level of factor site, $\beta_{j}$ is the fixed effect of the ${ }_{j}$ th level of factor clone (9 common clones to the three sites), $(\tau \beta)_{i j}$ is the interaction between the ${ }_{i}$ th level of factor site and the ${ }_{j}$ th level of factor clone, and $\varepsilon_{i j k}$ is the ${ }_{i j k}$ th random error.

Whereas inter-annual variations were analyzed independently in the 3 sites using all available clones in each site:

$y_{i j k}=\mu+\alpha_{i}+\beta_{j}+(\alpha \beta)_{i j}+\varepsilon_{i j k}$

where: $y_{i j k}$ is the ${ }_{k}$ th dendroplasticity variable observable in the ${ }_{i}$ th year and the ${ }_{j}$ th level of factor clone, $\mu$ is the overall mean effect, $\alpha_{i}$ is the fixed effect of ${ }_{i}$ th level of factor year, $\beta_{j}$ is the fixed effect of the all ${ }_{j}$ th level of factor clone, $(\alpha \beta)_{i j}$ is the interaction between the ${ }_{i} t h$ 
level of factor year and the all $j$ th level of factor clone, and $\varepsilon_{i j k}$ is the ${ }_{i j k}$ th random error. A similar model was used to compute phenotypic variation of the ring variables.

We used the following mixed-effects model to assess the degree of genetic control for dendroplasticity variables as well as for ring variables in each site and year. The model was run with the Imer function in R software (R Development Core Team 2008):

$y_{i}=\mu+\tau_{i}+\varepsilon_{i}$

where: $y_{i}$ is the ${ }_{i}$ th observed variable, $\mu$ is the overall fixed effect of the mean value, $\tau_{i}$ is the random effect of the ${ }_{i}$ th clone and $\varepsilon_{i}$ is the random error.

We calculated the degree of genetic determination or broad-sense heritability as:

$$
H^{2}=\frac{\sigma_{g}^{2}}{\sigma_{g}^{2}+\sigma_{\varepsilon}^{2}}
$$

where: $\sigma_{g}^{2}$ is the genetic component of variance, and $\sigma_{\varepsilon}^{2}$ is the error component of variance. The corresponding standard error of the heritability was estimated according to Falconer and Mackay (1996) as:

$$
\text { s.e. } H^{2}=\sqrt{\frac{\left((2 * 1+h a r-1) * H^{2}\right)^{2} *\left(1-H^{2}\right)^{2}}{(h a r *(h a r-1) *(n-1))}}
$$

where: har is the harmonic mean of individuals in each clone, and $n$ is the number of clones. We computed phenotypic $\left(r_{P}\right)$ and type A total genetic correlations ( $r_{G}$, additive and non additive portion) between the ring variables and dendroplasticity variables for each site and year. Phenotypic correlations were computed at individual level. Genetic correlations were assessed by means of the following equation:

$$
r_{G}=\frac{\left[\sigma_{g}(x+y)-\left(\sigma_{g}(x)+\sigma_{g}(y)\right)\right] / 2}{\sqrt{\sigma_{g}(x) * \sigma_{g}(y)}}
$$


where: $\sigma_{g}(x+y)$ is the genetic component of variance of the sum of trait 1 and trait 2, $\sigma_{g}(x)$ is the genetic component of variance of trait 1 , and $\sigma_{g}(y)$ is the genetic component of variance of trait 2 . Phenotypic and genetic correlations were computed by means of the $\mathrm{R}$ software (R Development Core Team 2008).

The approximate standard errors of $\mathrm{r}_{\mathrm{G}}$ were computed following Falconer and Mackay (1996) equation:

s.e. $r_{G}=\frac{1-r_{G}^{2}}{\sqrt{2}} \sqrt{\left[\frac{\text { s.e. } H_{x}^{2} * \text { s.e. } H_{y}^{2}}{H_{x}^{2} * H_{y}^{2}}\right]}$

where: $H_{x}^{2}$ and $H_{y}^{2}$ are the broad-sense heritabilities of trait 1 and trait 2, respectively, and s.e. $H_{x}^{2}$ and s.e. $H_{y}^{2}$ their respective standard errors.

\section{Results}

The adjusted coefficients of determination $\left(a d j R^{2}\right)$, as a measure of goodness-of-fit of the nonlinear regressions used to measure dendroplasticity, showed a good fit judging for the median value of $a d j R^{2}$ for all sites and years $\left(\operatorname{adj} R^{2}=0.91\right)($ Fig. 3). Only $6.6 \%$ of the trees showed values of $\operatorname{adj}^{2}$ inferior to 0.7 .

\section{Fig. 3}

We present in table 2 the mean and the associated standard deviation of dendroplasticity variables and microdensity variables taking into account all clones in each site and year-rings. Similar values were found using only the nine clones that were common to the three sites. For example, SLO in 1996 was -1.90, -1.12 and -0.86 in Lartimache, Sorèze and Chassenoix respectively. 


\section{Table 2}

Dendroplasticity variables varied across sites and years (Table 3). Inter-site analyses of variance showed the presence of significant variation for all dendroplasticity variables due to site and clone effects. Clone means were relatively stable across sites only for SLO, given the absence of significant interaction between sites and clones. Across years, almost all dendroplasticity variables (except INT in Lartimache and SUS in Chassenoix) showed significant variation due to year effect; whereas clone effect was always a significant part of the inter-annual phenotypic variation (Table 3). Inter-site and inter-annual significant genetic effects were found for microdensity variables (result not showed here).

\section{Table 3}

In table 4 we show the degree of genetic determination, the associated standard error and the coefficient of genetic variation $\left(\mathrm{CV}_{\mathrm{G}}\right)$ for all dendroplasticity and ring variables analyzed in this study. We found a weak to moderate broad-sense heritability for SLO (from $0.26 \pm 0.11$ to $0.52 \pm 0.10$ ), and SUS (from $0.27 \pm 0.09$ to $0.59 \pm 0.09$ ), whereas, weak to strong $H^{2}$ was found for INT (from $0.21 \pm 0.10$ to $0.70 \pm 0.08$ ). Almost all ring variables showed a moderate to high broad-sense heritability (except LW in Lartimache 1998, $\mathrm{H}^{2}=0.04$ and s.e. $\mathrm{H}^{2}=0.09$ ). The ring variable with the largest $H^{2}$ was MRD, followed by STD, MDP, LWD and MAD. $H^{2}$ of dendroplasticity variables was similar to that of the microdensity ring variables and higher than that of RW. The coefficient of genetic variation of RW, EW and LW was greater than those of dendroplasticity variables and density components. Between dendroplasticity variables, SLO had the highest genetic variation coefficient. High heritability values $\left(\mathrm{H}^{2}>\right.$ 
0.6) corresponded generally to lower values of genetic variation coefficient (result not showed here). Almost all breakpoints density and position had low to strong $H^{2}$ ranging from $0.20 \pm$ 0.11 to $0.75 \pm 0.07$ (results not showed).

\section{Table 4}

Phenotypic and genetic correlations (only those significantly different from zero) are shown in figure 4. Phenotypic and genetic correlations showed similar correlation patterns. In general, genotypic correlations were larger than their phenotypic counterparts. Over sites and years, higher increments of wood density (SLO) resulted in increments of STD ( $r_{P}$ from, LWD ( $r_{P}$ from and MAD ( $r_{P}$ from, and corresponding reductions in EWD ( $r_{P}$ from. For most sites and years, INT were positively correlated to STD ( $r_{P}$ from 0.47 to 0.88 ), LWD ( $r_{P}$ from 0.19 to 0.92 ), $\operatorname{MAD}$ ( $r_{P}$ from 0.20 to 0.91 ) and $\operatorname{MDP}$ ( $r_{P}$ from 0.20 to 0.86 ).

Concerning genetic correlations, despite only nine genetic entities are common to all sites, selection for some dendroplasticity variables affects similarly some microdensity variables. A main result is that negative genetic correlations were found between SLO and the following ring variables: $S T D\left(r_{G}\right.$ from $-0.44 \pm 0.11$ to $-1 \pm 0.07$ ), $L W D$ ( $r_{G}$ from $-0.21 \pm 0.29$ to $-0.61 \pm$ 0.10 ) and $\mathrm{MAD}\left(\mathrm{r}_{\mathrm{G}}\right.$ from $-0.26 \pm 0.30$ to $-0.70 \pm 0.13$ ). Note that a rapid change in within-ring wood density is achieved by a more negative value of SLO, thus increasing STD, LWD and MAD. On the other hand, positive genetic correlation was found with EWD ( $\mathrm{r}_{\mathrm{G}}$ from $0.34 \pm$ 0.16 to $0.88 \pm 0.03)$. In all sites and years we found positive genetic correlations between INT and MDP ( $r_{G}$ from $0.30 \pm 0.16$ to $0.93 \pm 0.01$ ), MAD ( $r_{G}$ from $0.26 \pm 0.21$ to $0.94 \pm 0.01$ ) and LWD ( $\mathrm{r}_{\mathrm{G}}$ from $0.20 \pm 0.26$ to $0.98 \pm 0.01$ ). Except for Chassenoix 1996 genetic correlations between INT and RW was negative, and between INT and MRD and between INT and STD 
were positive and relatively high ( $\mathrm{r}_{\mathrm{G}}$ from $-0.58 \pm 0.20$ to $-0.33 \pm 0.16$, from $0.51 \pm 0.07$ to $0.95 \pm$ 0.02 and from $0.59 \pm 0.05$ to $0.97 \pm 0.01$ respectively)

\section{Fig. 4}

Low to high ( $\mathrm{r}_{\mathrm{G}}$ from $0.19 \pm 0.20$ to $0.90 \pm 0.05$ ) positive genetic correlations were found between SLO and SUS. For the association between SLO and INT, only in Chassenoix and Lartimache in the year 1996 was different from zero, but of different sign $\left(\mathrm{r}_{\mathrm{G}} 0.83 \pm 0.10\right.$ and $0.44 \pm 0.11$ respectively). Between INT and SUS positive genetic correlation was found only in Sorèze and Chassenoix. In Sorèze we found the strongest positive genetic association $\left(\mathrm{r}_{\mathrm{G}}=\right.$ $0.70 \pm 0.05$ and $\mathrm{r}_{\mathrm{G}}=0.68 \pm 0.05$ in 1996 and 1998, respectively), whereas in Chassenoix the genetic correlation ranged from moderate to high ( $\mathrm{r}_{\mathrm{G}}$ from $0.43 \pm 0.35$ to $0.75 \pm 0.08$ in 2001 and 1996 respectively). In Lartimache the genetic correlations were not significantly different from zero.

\section{Discussion}

Within-ring wood record variation of tree-response to drought constraints can be interpreted in terms of plasticity of wood formation (Sanchez-Vargas et al. 2007). In the present study, we further develop this latter idea of fitting dendroplasticity records to drought constraints with the help of non-linear models. These latter models are usually preferred to linear models to construct norms of reaction through a gradient of environmental variation (David et al., 1998; Gibert et al., 2004; Valladares et al., 2007). Results suggest that dendroplasticity is better explained under such models, as indicated by the high values for the adjusted $\mathrm{R}^{2}$ that were obtained in the analyses. Furthermore, the proposed model is well described by a number of parameters that are easily linked to a biological meaning. For instance, SLO 
describes the rate to which an individual responds to a given drought constraint, it is a measure of biological reactivity. INT describes the maximum density at the end of the growing season, when the balance between water demand and water availability is unfavourable, and it can be interpreted as the maximum intensity of the response to drought. Finally, SUS is the value in the x-axes of the inflexion point of the curve for which corresponds the $50 \%$ of wood density increase: it describes tree's susceptibility to drought, where low SUS means high susceptibility to drought. We consider that these descriptors are ecologically more relevant than the microdensity ring variables alone, because the former descriptors are expressed as a function of environmental conditions. They appear to be genetically variable, with coefficients of genetic variation being generally larger than for the microdensity ring variables. They can serve to characterize single trees in terms of their acclimation to weather events, and make inferences on tree-response to the balance between water availability and water demand during the growing season.

In our study, climate variation during the growing season was described with the same DI for all sites and years. Using same DI with an identical set of genetic entities gave us the possibility to quantify phenotypic and genetic variation for dendroplasticity. Chassenoix was the site where trees showed higher susceptibility (lower SUS values) to drought. Significant between-site differences for SUS arguably reflect differences in soil moisture content. In Chassenoix, soil texture is sandy-clay, different from Lartimache and Sorèze, with clay-sandy and loam-clay-sandy soil texture, respectively. This soil texture affects water availability during the growing season: water deficit will appear earlier in Chassenoix than in Lartimache and Sorèze. All clones in Chassenoix showed a wood density increase at a lower DI, as if they were more stressed than in any of both other sites.

Almost all dendroplasticity variables showed significant year effects. This significant temporal variation for dendroplasticity could be associated to the timing of the drought 
events, and be observed in SLO differences. For instance, the year 1996 was characterized by a severe heat and drought wave (Bréda et al., 2004), while 1998 was marked by a moderate water deficit but occurring 20 days earlier in the growing season (weather data provided by Météo France).

It is well documented that wood density has consistently high levels of heritability across many species (Zobel and van Buijtenen, 1989; Cornelius, 1994; Zobel and Jett, 1995), and Douglas-fir is not an exception to that trend (Johnson and Gartner 2006). An important finding of our study is that clonal differences made up an essential component of observed variability for dendroplasticity, which denoted non negligible genetic variation. Broad-sense heritability for dendroplasticity variables was similar to that of most wood density parameters, and higher than those shown for RW, EW and LW. The coefficients of genetic variation for dendroplasticity variables were, generally, in-between those of wood density and those known for growth (except for SUS). INT's heritabilities were comparable to those of MRD, STD and latewood density parameters, whereas SLO and SUS heritabilities were similar to those of earlywood density parameters. High heritabilities and coefficients of genetic variation for dendroplasticity suggest that high selection responses should be expected from selection of clones following a given norm of reaction. Therefore, the existence of genotypic variation for dendroplasticity, the fact of being a trait linked to acclimation, its feasibility to measure and repeatability could all make dendroplasticity highly relevant as a novel trait in forest breeding programs.

High genetic correlations between two different characters hint at common genetic basis (Falconer and Mackay 1996). Genetic correlations can either facilitate or impede adaptation of either trait when counterpart is selected, whether the sign of the correlation and the direction of selection are synergic or not (Lynch and Walsh 1998; Etterson and Shaw 2001). An eventual selection on dendroplasticity descriptors, as the ones presented here, may result 
in correlated response in microdensity traits. For instance, increasing SLO would expectantly increase STD, MAD and LWD, while selecting for higher INT would result in higher MAD and LWD. SUS, on the other hand, would be increased if SLO is selected for higher values, in other words: a more rapid wood density increase over a drought index gradient is related to a high susceptibility of tree to drought constraints.

Note however that in this study we worked with clones and, therefore, it is thus not possible here to further decompose genetic variation into its elementary components, i.e. additive versus non additive sources of genetic variation. Only the additive component is subjected to recurrent selection to result in an evolving population. Therefore, adaptation requires additive variation, but the existence of the latter does not necessarily implies the quality of the former. We are still far from demonstrating the adaptive nature of dendroplasticity; this is beyond the scope of this study.

Plasticity could be considered adaptive when plastic genotypes show better acclimation and fitness over all environments than their non plastic counterparts (Thompson, 1991). Some recent results start to suggest that there is a link between dendroplasticity and adaptation. Martinez-Meier et al (2008b) show the existence of significant differences for ring microdensity parameters between alive and dead neighbouring Douglas-fir trees after the 2003 drought and heat wave in France. In this study, surviving trees had consistently higher mean ring density, latewood density, latewood proportion and maximum ring density than their dead counterparts. Some authors (Waring and Running, 1978; Schiller and Cohen, 1995; Domec and Gartner, 2002; Beedlow et al., 2007) suggest that in Douglas-fir ring density components are related to adaptive hydraulic properties of wood: higher latewood/earlywood ratio for density could be then interpreted as a strategy to grow in favourable initial wet conditions during the spring and dry stressing conditions in the summer. Trees lacking such capacity of changing greatly their density over the growing season would be penalized. 
Further research is needed though, where dendroplasticity is compared between sane and suffering trees, in order to validate the adaptive value of dendroplasticity.

\section{Conclusions}

Dendroplasticity is a powerful tool providing retrospective, synthetic and easy-to-interpret information about tree response to the variation of balance between water availability and water demand during the growing season. The model presented and used in this study is an improvement of the model developed by Sanchez-Vargas et al (2007). The proposed model is well described by a number of parameters that are easily linked to a biological meaning, like the biological reactivity to a drought constraint, the maximum intensity of the response to drought, and tree's susceptibility to drought. Still, the synchronization is a limiting phase, as it requires year-rings including false rings. New refinements are necessary in order to extend this type of analysis to any form of ring of softwood trees grown under temperate climate.

\section{Acknowledgements}

We would like to thank Frédéric Millier for the X-ray microdensity profiles and FCBA (forêt, cellulose, bois-construction, ameublement, www.fcba.fr/accueil.php) for providing the genetic tests and the plant material that was used in this study. 


\section{References}

Beedlow, P., Tingey, D., Waschmann, R.; Phillips, L., Johnson, M., 2007. Bole water content shows little seasonal variation in century-old Douglas-fir trees. Tree Physiology 27, 737-747.

Bradshaw, A.D., 1965. Evolutionary significance of phenotypic plasticity in plants. Advances in Genetics 13, 115-155.

Bradshaw, A.D., Hardwick, K., 1989. Evolution and stress-genotypic components. Biological Journal of the Linnean Society 37, 137-155.

Bréda, N., Granier, A., Aussenac, G., 2004. La sécheresse de 2003 dans le contexte climatique des 54 dernières années: analyse écophysiologique et influence sur les arbres forestiers. Revue Forestière Française 56, 109-131.

Bréda, N., Huc, R., Granier, A., Dreyer, E., 2006. Temperate forest trees and stands under severe drought: a review of ecophysiological responses, adaptation processes and longterm consequences. Annals of Forest Science 63, 625-644.

Campbell, R., Sugano, A., 1975. Phenology of bud burst in Douglas fir relatd to provenance, photoperiod, chilling and flushing temperatue. Botanical Gazette 136 (3), 290298.

Cornelius, J., 1994. Heritabilities and additive genetic coefficients of variation in forest trees. Canadian Journal of Forest Research 24, 372-379.

David, J.R., Gibert, P., Gravot, E., Pétavy, G., Morin, J.P., Karan, D., Moreteau B., 1997. Phenotypic plasticity and developmental temperature in Drosophila : analysis and significance of reaction norms of morphometrical traits. Journal of Thermal Biology 22 (6), 441-45 I.

De Champs, J., 1997. Le Douglas. Afocel, Paris, France. 
De Martonne, E., 1926. L’indice d’aridité. Bulletin de l’Association des géographes français 9, 3-5.

DeWitt, T., Scheiner, S.M., 2004. Phenotypic Plasticity. Functional and Conceptual Approaches. Oxford University Press, Inc, UK.

Domec, J.C., Gartner, B.L., 2002. How do water storage differ in coniferous earlywood and latewood? Journal of Experimental Botany 53, 2369-2379.

DSF, 2004. Sécheresse et canicule de l'été 2003. Quelle incidence visuelle sur les peuplements forestiers? Information Santé des Forêt. URL:

http://www.agriculture.gouv.fr/spip/IMG/pdf/isfweb_long.pdf

Etterson J.R., Shaw, R.G., 2001. Constraint to adaptive evolution in response to global warming. Science 294 (5), 151-154.

Falconer, D.S., Mackay, T.F., 1996. Introduction to Quantitative Genetics. 4th ed. Longmans Green, Harlow, Essex, UK.

Fuller, T., 2003. The Integrative Biology of Phenotypic Plasticity. Book Review, Biology and Philosophy 18, 381-389.

Gibert, P., Moreteau, B., David J.R., 2004. Phenotypic plasticity of body pigmentation in Drosophila melanogaster. Genetic repeatability of quantitative parameters in two successive generations. Heredity 92, 499-507.

Glerum, C., 1970. Drought ring formation in conifers. Forest Science 16, 246-248.

Guay, R., Gagnon, R., Morin, H., 1992. A new automatic and interactive tree ring measurement system based on a line scan camera. Forest Chronicle 68, 138-141.

Hacke, U., Sperry, J., Pockman, W., Davis, S., McCulloh, K., 2001. Trends in wood density and structure are linked to prevention of xylem implosion by negative pressure. Oecologia 126, 457-461. 
IPCC, 2001. Climate Change 2001. Synthesis report. Summary for policymakers. URL: http://www.ipcc.ch/pdf/climate-changes-2001/synthesis-spm/synthesis-spm-en.pdf

IPCC, 2007. Climate Change 2007: The Physical Science Basis. Summary for Policymakers. Contribution of Working Group I to the Fourth Assessment Report of the Intergovernmental Panel on Climate Change. URL: http:/www.ipcc.ch/SPM2feb07.pdf

Johnson, G.R., Gartner, B., 2006. Genetic variation in basic density and modulus of elasticity of coastal Douglas-fir. Tree Genetics \& Genomes 3, 25-33.

Larson, P.R,. 1963. The indirect effect of drought on tracheid diameter in red pine. Forest Science 9, 52-62.

Larson, P.R., 1994. The vascular cambium, development and structure, Springer Verlag, Heidelberg \&, Berlin, Germany.

Lynch, M., Walsh, B., 1998. Genetics and analysis of quantitative traits. Sinauer Associates, Inc, Massachusetts, US.

Martinez-Meier, A., Sanchez, L., Dalla-Salda, G., Pastorino, M., Gautry, J.Y., Gallo, L., Rozenberg, P., 2008a. Genetic control of the tree-ring response of Douglas-fir (Pseudotsuga menziesii (Mirb.) Franco) to the 2003 drought and heat-wave in France. Annals of Forest Science 65 (102), DOI: 10.1051/forest:2007074.

Martinez-Meier, A., Sanchez, L., Pastorino, M., Gallo, L., Rozenberg, P., 2008b. What is hot in tree rings? The wood density of surviving Douglas-firs to the 2003 drought and heat wavel. Forest Ecology and Management 256 (4), 837-843.

Meehl, G., Tebaldi, C., 2004. More Intensive, More Frequent, and Longer Lasting Heat Waves in the 21st Century. Science 305, 994.

Noss, R., 2002. Beyond Kyoto, Forest Management in a Time of Rapid Climate Change. Conservation Biology 15 (3), 578-590. 
Polge, H., 1966. Etablissement des courbes de variations de la densité du bois par exploration densitométrique de radiographies d'échantillons prélevés à la tarière sur des arbres vivants. Application dans les domaines technologiques et physiologiques. $\mathrm{PhD}$ thesis, Université de Nancy, Nancy.

R Development Core Team 2008. R: A language and environment for statistical computing, R Foundation for Statistical Computing. Vienna, Austria. URL: http://www.Rproject.org.

Rathgeber C., Decoux V., Leban J.M., 2006. Linking intra-tree-ring wood density variations and tracheid anatomical characteristics in Douglas fir (Pseudotsuga menziesii (Mirb.) Franco). Annals of Forest Science 63, 699-706.

Rehfeldt G., Wykoff W., Ying C., 2001. Physiologic Plasticity, Evolution and Impacts of a Changing Climate on Pinus contorta. Climate Change 50, 355-376.

Rehfeldt, G., Tchebakova, N.M., Parfenova, Y., Wykoff, W., Kuzmina, N., Milyutin, L., 2002. Intraspecific responses to climate in Pinus sylvestris. Global Change Biology 8 (9), 912-929.

Rozenberg, P., Van Loo, J., Hannrup, B., Grabner, M., 2002. Clonal variation fo wood density record of cambium reaction to water deficit in Picea abies (L.) Karst. Annals of Forest Science 59, 533-540.

Rozenberg, P., Pâques, L., 2004. Evidence of the effect of the climate of year 2003 on Douglas-fir and larch wood formation in France. In: Abstracts of Scientific Conference, Impacts of the Drought and Heat in 2003 on Forests. Freiburg, Germany, 17-19 November.

Rozenberg, P., Schüte, G., Ivkovich, M., Bastien, C., Bastien, J.C., 2004. Clonal variation of indirect cambium reaction to within-growing season temperature changes in Douglas-fir. Forestry 77, 257-268. 
Sanchez-Vargas, N., Sanchez, L., Rozenberg, P., 2007. Plastic and adaptive response to weather events: a pilot study in a maritime pine tree ring, Canadian Journal of Forest Research 37, 2090-2095.

Sarkar, S., 1999. From the Reaktionsnorm to the Adaptive Norm: The Norm of Reaction, 1909-1960. Biology and Philosophy 14, 235-252.

Savolainen, O., Bokma, F., García-Gil, R., Komulainen, P., Repo, T., 2004. Genetic variation in cessation of growth and frost hardiness and consequences for adaptation of Pinus sylvestris to climatic changes. Forest Ecology and Management 197, 79-89.

Silen, R., 1978. Genetics of Douglas-fir. USDA Forest Service, Research Paper, WO35: $34 \mathrm{p}$.

St. Clair, J.B., Howe G., 2007. Genetic maladaptation of coastal Douglas-fir seedlings to future climates. Global Change Biology 13, 1441-1454.

Stott, P., Stone, D., Allen, M., 2004. Human contribution to the European heat wave of 2003. Nature 432, 610-614.

Sultan, S., 2004. Promising directions in plant phenotypic plasticity. Perspectives in Plant Ecology, Evolution and Systematics 6, 227-233.

Taiz, L., Zeiger, E., 2006. Plant physiology. 4th ed. Sinauer Associates, Inc, Massachusetts, US.

Thivolle-Cazat, A., 2004. Le Douglas en France : une ressource résineuse en pleine expansion. URL: http://www.afocel.fr/Foret/Ressources/Douglas/4\%20pagesF.Douglas.pdf Thompson, J.D., 1991. Phenotypic plasticity as a component of evolutionary change. Trends in Ecology and Evolution 6, 246-249.

Valladares, F., Gianoli, E., Gómez, J.M., 2007. Ecological limits to plant phenotypic plasticity. Review. New Phytologist 176, 749-763. 
Waring, R., Running, S., 1978. Sapwood water storage: its contribution to transpiration and effect upon water conductance through the stems of old-growth Douglas-fir. Plant Cell and Environment 1, 131-140.

Zahner, R., 1968. Water deficits and growth of trees. In: Kozlowski T.T. (eds.) Water deficits and plant growth, pp. 191-254. Academic Press, NY, US.

Zamudio, F., Rozenberg, P., Baettig, R., Vergara, A., Yañez, M., Gantz, C., 2005.

Genetic variation of wood density components in a radiata pine progeny test located in the south of Chile. Annals of Forest Science 62, 105-114.

Zobel, B.J., Jett, J.B., 1995. Genetics of wood production. Springer-Verlag, Berlin, Germany.

Zobel, B., van Buijtenen, J., 1989. Wood variation its causes and control. SpringerVerlag, Berlin, Germany. 


\section{FIGURE LEGENDS}

Fig. 1 Illustrates an example of the characteristic curve shapes (two marked peaks) showing the seven identified breakpoints found in all trees for one analyzed year and site (Figure 1a) and daily drought index variation (dotted line) and the smoothed values (solid line) used to synchronize whiting-ring wood density variation with weather variation (Figure 1b). Example for the same year and site.

Fig. 2 Illustrative example of the non-linear Boltzmann models describing dendroplasticity.

Fig. 3 Distributions of the adjusted $\mathrm{R}^{2}$ non-linear regression models fitted at tree level. The vertical line is the median value. The minimum and maximum value of adj $R^{2}$ was 0.53 and 0.99 respectively.

Fig. 4 Phenotypic (a) and genetic (b) correlations (only genetic correlations significantly different from zero) between dendroplasticity and microdensity variables. Each symbol

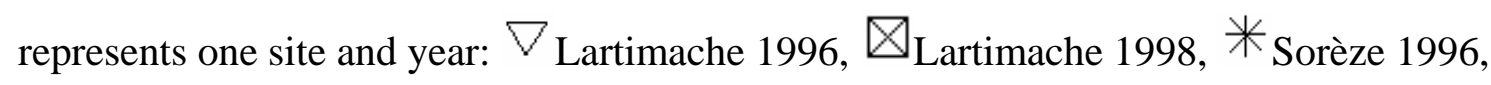
$\bigoplus$ Sorèze 1998, $\triangle$ Chassenoix 1996 and $\diamond$ Chassenoix 2001. 
TABLES

Table 1 Sites, years, period between first and last identified breakpoint, number of breakpoints and the maximum and minimum DI computed in each site and year.

\begin{tabular}{lcccc}
\hline \hline \multicolumn{1}{c}{ Site } & Year & $\begin{array}{c}\text { breakpoint period } \\
\text { from -to }\end{array}$ & $\begin{array}{c}\text { number of } \\
\text { breakpoints }\end{array}$ & $\begin{array}{c}\text { DI } \\
\text { max - min }\end{array}$ \\
\hline Lartimache & 1996 & April 15 $5^{\text {st }}-30^{\text {th }}$ August & 7 & $9.7-4.9$ \\
Lartimache & 1998 & April $1^{\text {st }}-10^{\text {th }}$ August & 10 & $8.5-2.1$ \\
Sorèze & 1996 & April 10 $10^{\text {er }}-30^{\text {th }}$ August & 10 & $10.8-5.1$ \\
Sorèze & 1998 & April $4^{\text {th }}-27^{\text {th }}$ July & 8 & $10.2-3.2$ \\
Chassenoix & 1996 & March $25^{\text {th }}-31^{\text {th }}$ July & 7 & $9.1-2.6$ \\
Chassenoix & 2001 & April $1^{\text {er }}-3^{\text {er }}$ August & 8 & $8.7-1.9$ \\
\hline
\end{tabular}


1 Table 2 Mean values and associated standard deviation of microdensity variables and dendroplasticity taking into account all Douglas-fir

2 clones in each site and year.

\begin{tabular}{|c|c|c|c|c|c|c|}
\hline \multirow[t]{2}{*}{ Variables } & \multicolumn{6}{|c|}{ Sites and years } \\
\hline & $\begin{array}{c}\text { Lartimache } \\
1996\end{array}$ & $\begin{array}{c}\text { Lartimache } \\
1998\end{array}$ & $\begin{array}{c}\text { Sorèze } \\
1996 \\
\end{array}$ & $\begin{array}{c}\text { Sorèze } \\
1998 \\
\end{array}$ & $\begin{array}{c}\text { Chassenoix } \\
1996\end{array}$ & $\begin{array}{c}\text { Chassenoix } \\
2001\end{array}$ \\
\hline \multicolumn{7}{|l|}{ Ring variables } \\
\hline RW (mm) & $5.99 \pm 1.57$ & $5.76 \pm 1.64$ & $8.09 \pm 1.50$ & $6.69 \pm 1.41$ & $6.86 \pm 1.40$ & $8.66 \pm 2.09$ \\
\hline $\operatorname{MRD}\left(\mathrm{gr} / \mathrm{cm}^{3}\right)$ & $0.47 \pm 0.05$ & $0.46 \pm 0.05$ & $0.38 \pm 0.03$ & $0.41 \pm 0.04$ & $0.41 \pm 0.04$ & $0.37 \pm 0.03$ \\
\hline $\operatorname{MDP}\left(\mathrm{gr} / \mathrm{cm}^{3}\right)$ & $0.50 \pm 0.04$ & $0.48 \pm 0.03$ & $0.39 \pm 0.02$ & $0.41 \pm 0.03$ & $0.48 \pm 0.03$ & $0.46 \pm 0.03$ \\
\hline $\operatorname{MID}\left(\mathrm{gr} / \mathrm{cm}^{3}\right)$ & $0.18 \pm 0.03$ & $0.17 \pm 0.02$ & $0.17 \pm 0.02$ & $0.17 \pm 0.01$ & $0.18 \pm 0.03$ & $0.17 \pm 0.02$ \\
\hline $\mathrm{EW}(\mathrm{mm})$ & $3.35 \pm 1.13$ & $2.65 \pm 1.20$ & $3.78 \pm 1.26$ & $2.75 \pm 1.04$ & $4.33 \pm 1.38$ & $6.25 \pm 2.02$ \\
\hline $\operatorname{EWD}\left(\mathrm{gr} / \mathrm{cm}^{3}\right)$ & $0.25 \pm 0.04$ & $0.24 \pm 0.03$ & $0.24 \pm 0.03$ & $0.22 \pm 0.03$ & $0.27 \pm 0.04$ & $0.26 \pm 0.04$ \\
\hline EWP (\%) & $55.18 \pm 9.16$ & $44.75 \pm 10.02$ & $46.41 \pm 11.11$ & $40.60 \pm 9.97$ & $62.18 \pm 10.99$ & $71.20 \pm 9.39$ \\
\hline $\operatorname{MAD}\left(\mathrm{gr} / \mathrm{cm}^{3}\right)$ & $0.82 \pm 0.07$ & $0.79 \pm 0.06$ & $0.61 \pm 0.05$ & $0.65 \pm 0.05$ & $0.77 \pm 0.04$ & $0.76 \pm 0.06$ \\
\hline LW (mm) & $2.64 \pm 0.77$ & $3.11 \pm 0.77$ & $4.30 \pm 1.10$ & $3.94 \pm 0.96$ & $2.53 \pm 0.75$ & $2.40 \pm 0.73$ \\
\hline $\operatorname{LWD}\left(\mathrm{gr} / \mathrm{cm}^{3}\right)$ & $0.69 \pm 0.06$ & $0.65 \pm 0.07$ & $0.50 \pm 0.04$ & $0.53 \pm 0.04$ & $0.63 \pm 0.04$ & $0.63 \pm 0.05$ \\
\hline STD & $0.23 \pm 0.03$ & $0.21 \pm 0.03$ & $0.14 \pm 0.03$ & $0.16 \pm 0.02$ & $0.18 \pm 0.02$ & $0.18 \pm 0.02$ \\
\hline \multicolumn{7}{|c|}{ Dendroplasticity variables } \\
\hline SLO & $-2.00 \pm 0.30$ & $-0.66 \pm 0.17$ & $-1.12 \pm 0.24$ & $-0.60 \pm 0.10$ & $-0.85 \pm 0.57$ & $-0.66 \pm 0.10$ \\
\hline INT & $0.74 \pm 0.07$ & $0.75 \pm 0.08$ & $0.54 \pm 0.05$ & $0.65 \pm 0.07$ & $0.74 \pm 0.06$ & $0.64 \pm 0.09$ \\
\hline SUS & $5.63 \pm 0.10$ & $4.23 \pm 0.64$ & $5.74 \pm 0.23$ & $5.31 \pm 0.40$ & $3.82 \pm 0.63$ & $3.90 \pm 0.53$ \\
\hline
\end{tabular}


4 Table 3 Results of the inter-site and inter-annual analysis of variance (F value and code

5 for associated probability) using 9 common clones and all clones in each site,

6 respectively.

\begin{tabular}{|c|c|c|c|}
\hline \multicolumn{4}{|c|}{ Inter-site phenotypic variation for year 1996} \\
\hline \multirow[t]{2}{*}{ Source of variation } & \multicolumn{3}{|c|}{ Dendroplasticity } \\
\hline & SLO & INT & SUS \\
\hline Site & $90.63 * * *$ & $222.39 * * *$ & $624.47 * * *$ \\
\hline Clone & $2.28 *$ & $4.34 * * *$ & $7.99 * * *$ \\
\hline Interaction & $1.51 \mathrm{~ns}$ & $4.12 * * *$ & $5.07 * * *$ \\
\hline \multicolumn{4}{|c|}{ Inter-annual phenotypic variation } \\
\hline & SLO & INT & SUS \\
\hline \multicolumn{4}{|l|}{ Lartimache } \\
\hline Year & $2938.65^{* * *}$ & $0.62 \mathrm{~ns}$ & $301.12 * * *$ \\
\hline Clone & $4.96 * * *$ & $5.74 * * *$ & $3.16 * * *$ \\
\hline Interaction & $2.45 * * *$ & $1.74^{*}$ & $4.29 * * *$ \\
\hline \multicolumn{4}{|l|}{ Sorèze } \\
\hline Year & $601.59 * * *$ & $448.85 * * *$ & $181.87 * * *$ \\
\hline Clone & $5.64 * * *$ & $17.27 * * *$ & $8.81 * * *$ \\
\hline Interaction & $1.88^{*}$ & $2.40^{* *}$ & $3.46 * * *$ \\
\hline \multicolumn{4}{|l|}{ Chassenoix } \\
\hline Year & $12.13 * * *$ & $91.07 * * *$ & $0.07 \mathrm{~ns}$ \\
\hline Clone & $2.25^{* *}$ & $1.96 * *$ & $3.17 * * *$ \\
\hline Interaction & $1.65 *$ & $2.56 * * *$ & $3.09 * * *$ \\
\hline
\end{tabular}

7 Codes for associated probability: between 0 and $0.001=* * *$, between 0.001 and 0.01

$8=* *$, between 0.01 and $0.05=*$, and $>0.5=n s$.

9 


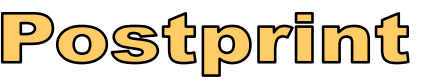

Version définitive du manuscrit publié dans / Final version of the manuscript published in :

Table 4 Degrees of genetic determination (heritability in broad sense and their associated standard error) and genetic variation $\left(\mathrm{CV}_{\mathrm{G}}\right)$ for ring microdensity variables and dendroplasticity assessed.

\begin{tabular}{|c|c|c|c|c|c|c|c|c|c|c|c|c|}
\hline \multirow[t]{3}{*}{ Variables } & \multicolumn{12}{|c|}{ Sites and years } \\
\hline & $\begin{array}{c}\text { Lartimache } \\
1996\end{array}$ & & $\begin{array}{c}\text { Lartimache } \\
1998\end{array}$ & & $\begin{array}{c}\text { Sorèze } \\
1996\end{array}$ & & $\begin{array}{c}\text { Sorèze } \\
1998\end{array}$ & & $\begin{array}{c}\text { Chassenoix } \\
1996\end{array}$ & & $\begin{array}{c}\text { Chassenoix } \\
2001\end{array}$ & \\
\hline & $\mathrm{H}^{2}$ (s.e. $\mathrm{H}^{2}$ ) & $\mathrm{CV}_{\mathrm{G}}$ & $\mathrm{H}^{2}$ (s.e. $\left.\mathrm{H}^{2}\right)$ & $\mathrm{CV}_{\mathrm{G}}$ & $\mathrm{H}^{2}\left(\right.$ s.e. $\left.\mathrm{H}^{2}\right)$ & $\mathrm{CV}_{\mathrm{G}}$ & $\mathrm{H}^{2}\left(\right.$ s.e. $\left.\mathrm{H}^{2}\right)$ & $\mathrm{CV}_{\mathrm{G}}$ & $\mathrm{H}^{2}$ (s.e. $\mathrm{H}^{2}$ ) & $\mathrm{CV}_{\mathrm{G}}$ & $\mathrm{H}^{2}\left(\right.$ s.e. $\left.\mathrm{H}^{2}\right)$ & $\mathrm{CV}_{\mathrm{G}}$ \\
\hline \multicolumn{13}{|c|}{ Ring variables } \\
\hline RW & $0.32(0.09)$ & 14.26 & $0.20(0.10)$ & 12.37 & $0.30(0.11)$ & 9.72 & $0.18(0.10)$ & 8.57 & $0.36(0.11)$ & 11.88 & $0.35(0.11)$ & 13.8 \\
\hline MRD & $0.53(0.08)$ & 8.08 & $0.63(0.08)$ & 8.45 & $0.58(0.09)$ & 6.27 & $0.60(0.09)$ & 6.87 & $0.67(0.08)$ & 8.60 & $0.65(0.08)$ & 7.41 \\
\hline EW & $0.36(0.09)$ & 19.39 & $0.27(0.11)$ & 22.37 & $0.51(0.11)$ & 22.9 & $0.40(0.11)$ & 23.04 & $0.52(0.10)$ & 22.67 & $0.41(0.10)$ & 19.87 \\
\hline EWD & $0.35(0.09)$ & 9.46 & $0.64(0.08)$ & 11.69 & $0.19(0.10)$ & 5.97 & $0.53(0.10)$ & 9.45 & $0.51(0.10)$ & 10.55 & $0.27(0.11)$ & 5.75 \\
\hline EWP & $0.43(0.09)$ & 10.36 & $0.26(0.11)$ & 10.96 & $0.42(0.11)$ & 14.8 & $0.54(0.10)$ & 17.62 & $0.49(0.10)$ & 11.86 & $0.51(0.10)$ & 9.01 \\
\hline MAD & $0.63(0.07)$ & 6.76 & $0.51(0.09)$ & 5.08 & $0.59(0.09)$ & 5.54 & $0.71(0.08)$ & 6.80 & $0.36(0.11)$ & 2.98 & $0.35(0.10)$ & 4.27 \\
\hline LW & $0.33(0.09)$ & 16.21 & $0.05(0.09)$ & 5.15 & $0.17(0.10)$ & 10.11 & $0.26(0.11)$ & 12.07 & $0.23(0.11)$ & 13.51 & $0.40(0.11)$ & 18.54 \\
\hline INT & $0.58(0.08)$ & 7.26 & $0.29(0.11)$ & 5.55 & $0.70(0.08)$ & 8.36 & $0.70(0.08)$ & 8.32 & $0.33(0.11)$ & 4.51 & $0.21(0.10)$ & 6.38 \\
\hline SUS & $0.27(0.09)$ & 0.85 & $0.36(0.11)$ & 8.80 & $0.58(0.09)$ & 2.93 & $0.59(0.10)$ & 5.79 & $0.54(0.10)$ & 11.92 & $0.13(0.09)$ & 4.70 \\
\hline
\end{tabular}

